Article

\title{
The Rise of the Androgynous Princess: Examining Representations of Gender in Prince and Princess Characters of Disney Movies Released 2009-2016
}

\author{
Benjamin Hine ${ }^{1, *(\mathbb{D})}$, Dawn England ${ }^{2}$, Katie Lopreore ${ }^{3}$, Elizabeth Skora Horgan ${ }^{4}(\mathbb{D})$ and \\ Lisa Hartwell ${ }^{5}$ \\ 1 Department of Psychology, University of West London, St Mary's Road, London W5 5RF, UK \\ 2 School of Health and Education, Middlesex University Dubai, Knowledge Park, Block 16, Dubai, UAE; \\ D.england@mdx.ac.ae \\ 3 Department of Nursing, Middle Tennessee University, 13-1 E Main Street, Murfreesboro, TN 37132, USA; \\ kl3t@mtmail.mtsu.edu \\ 4 Department of Human Development and Family Studies, University of Wisconsin-Madison, Madison, \\ WI 53706, USA; eskora@wisc.edu \\ 5 Master's Counseling Department, Messiah College, One College Avenue, Mechanicsburg, PA 17055, USA; \\ lisahartwell13@gmail.com \\ * Correspondence: Ben.Hine@uwl.ac.uk; Tel.: +44-0208-209-4571
}

Received: 5 October 2018; Accepted: 16 November 2018; Published: 22 November 2018

check for updates

\begin{abstract}
Previous quantitative research examining Disney movies has highlighted that whilst prince characters display largely balanced gender profiles, princesses exhibit biased gender role portrayals-performing mostly feminine characteristics, rarely participating in rescue behavior, and concluding movies in romantic relationships with the prince. However, such research, as well as public commentary, has also suggested that princess characters in movies released across the 2000s and 2010s may have more positive gender role portrayals. This study aimed to test these assertions by utilizing content coding analysis to examine the behavioral characteristics, rescue behavior, and romantic conclusions of prince and princess characters in five iconic Disney films released between 2009 and 2016 (The Princess and the Frog, Tangled, Brave (released under Pixar), Frozen, and Moana). Comparisons were also made with earlier titles to assess historical changes. Results showed that princesses in "2000s to 2010s" movies exhibited an almost equal number of masculine and feminine behaviors, thus demonstrating more egalitarian profiles over time. In contrast, princes appeared to adopt a more feminine behavioral profile in later movies. In addition, characters engaged in equal numbers of rescue behaviors, and princesses were more likely to remain single in "2000s to 2010s" movies. Results therefore suggest that Disney is indeed presenting more diverse, androgynous, balanced characters to viewers, and the theoretical and practical implications for the socialization of young child viewers are discussed.
\end{abstract}

Keywords: Disney; princess; prince; gender roles; content coding analysis; children's media

\section{Introduction}

\subsection{Gender Role Portrayal in Children's Visual Media}

Over the past 25 years, several studies have demonstrated that male characters in cartoons and other television programs are given much more prominence and appear more frequently (Aubrey and Harrison 2004; Calvert et al. 2003; Thompson and Zerbinos 1995), display more aggression (Luther and Legg 2010; Signorielli et al. 1995), display more planning (Browne 1998), 
engage in more of almost all the noted behaviors (Hentges and Case 2013) and talk significantly more (Hentges and Case 2013). Scholars have therefore suggested that representations of both male and female gender roles in children's programming are frequently too narrow and stereotypical (Leaper et al. 2002; Signorielli 2001; Steyer 2014). Negative representations of gender are also found in other forms of children's media, such as video games. For example, male gaming characters are much more likely to be aggressive, with female characters more likely to be sexualized, scantily clad, and to show a mix of sex and aggression (Dill and Thill 2007). Patterns such as these are reflected in media for adults, as demonstrated in a number of comprehensive reviews (Rudy et al. 2010a, 2010b). Women are still vastly under-represented across a range of settings (e.g., television, movie and printed media) and, when they are shown, tend to be given restricted and traditional portrayals. Women are also often sexualized or subordinated in various ways, and portrayed as fulfilling traditional roles such as homemaking, as non-professionals, as wives or parents, or as sexual gatekeepers (Collins 2011; Lemish 2010). Representations of men also remain largely unchanged, and centered around traditionally masculine traits (Signorielli 2001).

However, a number of studies suggest positive advances in gender role portrayal within children's media in recent decades, finding, for example, a great deal of gender neutrality across a number of first and second grade children's television programs (Aubrey and Harrison 2004; Baker and Raney 2007). Furthermore, when examining the most popular children's television networks in the U.S. (i.e., the Disney Channel, Cartoon Network and Nickelodeon) Hentges and Case (2013) found few differences in stereotyped behaviors when comparing male and female characters in post-1980, versus pre-1980, cartoons. Taken together, such research suggests that, whilst gender role portrayals in children's media continue to be problematic, a possible progression exists towards less narrow representations of gender, which, interestingly, were most exemplified on the Disney Channel, where the fewest differences in gendered behavior were found (Hentges and Case 2013).

\subsection{The Relationship between Media and Gender Development}

Several theories highlight the importance of such gendered information to the development of children's sense of gender identity (see Blakemore et al. 2009 for a review). For example, both Social Cognitive Theory (Bussey and Bandura 1999) and Identity Theory (Hogg et al. 1995) suggest that environmental models (such as parents, peers, or those in the media) help to transmit and teach gender norms and stereotypes to young children, particularly through modelling. Constructivist approaches also stress the importance of environmental stimuli, for example in Gender Schema Theory (Bem 1981; Martin and Halverson 1981), which proposes that children internalize their observations and experiences into cognitive frameworks or schemas, which subsequently guide their behavior (Graves 1999; Martin et al. 2002). Several approaches identify the media specifically as a key socializing agent for gender role development (Signorielli 2001). For example, cultivation theory proposes that visual media, such as television and film, may provide a particularly important mechanism for the development of concepts regarding social behavior and norms (Gerbner et al. 1994, 1980), and several studies directly highlight the impact of media consumption on subscription to traditional gender role representations (Coyne et al. 2014; Frueh and McGhee 1975; Herrett-Skjellum and Allen 1996; Hust and Brown 2008; Signorielli 1990; Williams 1981).

Social Role Theory (Eagly 2013; Eagly et al. 2000) provides a particularly important framework for assessing change in gender roles, and their representations, over time. Similar to many of the theories outlined above, it proposes that cultural expectations present in society influence an individual's roles and behaviors (Mead 1934), and that beliefs about gender are derived from observations of role performances exhibited in their environment. Importantly, this theory argues that culturally expected gendered roles and behaviors which children learn are dynamic and are influenced by changing cultural norms and environmental contexts (Eagly 2013). It therefore follows that any substantive shifts in societal constructions of gender roles (for example, increased flexibility afforded to women) would, and should, be reflected in changes to representations in the media. Such observations are 
particularly pertinent to prolific media forms, such as Disney movies, due to their contribution in shaping societal fabrics (Bryman 1999).

\subsection{Representations of Women in Disney Movies}

As such, several studies have investigated gender role portrayals by female characters in Disney feature movies released before 2010. For example, in 2011, England and colleagues produced a comprehensive quantitative analysis of Disney Princess movies released between 1937 and 2009, arguing prince and princess characters exhibited many traditionally gendered behaviors (England et al. 2011). This was found when examining the frequency of masculine and feminine characteristics, as well as rescue behavior (i.e., rarely performed by the princess) and romantic outcomes (i.e., the conclusion often resulted in heterosexual, heteronormative, 'love at first sight' marriage). These results are supported by studies using qualitative approaches which have criticized traditional or stereotypical portrayals of women (Matyas 2010), commenting on aspects such as their over sexualization and focus on the exotic (Lacroix 2004), sacrifice to higher or communal goals (Dundes 2001), and troubled relationships with male characters (Béres 1999; Do-Rozario 2004). Towbin and colleagues (2004) further highlighted that, in 26 Disney movies released between 1937 and 2000, female characters: have their appearance valued more than their intellect, were helpless and in need of protection, were domestic and likely to marry, and, if overweight, were ugly, unpleasant and unmarried.

Davis (2006) provides perhaps the most thorough qualitative appraisal of women in Disney movies up until 2003, largely from a film studies perspective. Several themes, similar to those in Towbin et al. (2004), were found for 'Classic Years' Disney women (1937-1967), including happiness found through marriage (e.g., Anita in One Hundred and One Dalmatians), and passivity, exemplified most strongly by the three princesses of this age, Snow White, Cinderella and Aurora (from Snow White and the Seven Dwarfs, Cinderella, and Sleeping Beauty respectively). In contrast, 'Eisner Era' Disney women (1989-2005) garner more favorable, captured most clearly by the evolution of Disney princesses (namely, Ariel, Jasmine, Pocahontas and Kida, from The Little Mermaid, Aladdin, Pocahontas and Atlantis: The Lost Empire respectively) into more well-rounded, independent, strong-willed, determined characters, insistent on being true to themselves. The introduction of 'tough gals', such as Megara in Hercules, is also presented as cause for celebration, whose strength, brashness and confidence are in stark contrast to their timid counterparts of old (Primo 2018). Nonetheless, the characters outlined above are still not entirely gender-progressive, and each still has their significant flaws (take, for example, Ariel's willingness to risk her life just for the possibility of finding love). Furthermore, the storylines of 'good daughter' characters (such as Belle, Mulan and Jane, from Beauty and the Beast, Mulan, and Tarzan respectively), whilst again containing some progressive elements, still present archetypal portrayals in which women are rewarded for acting selflessly for others, and where women engage in a lateral move between submission to a fatherly male authority figure, and a husbandly one. Taken together, such studies suggest that, whilst gender portrayals in pre-2003 Disney movies have improved over time, they are by no means in-keeping with societal developments in gender equity (Wiersma 2001). As summarized by Davis (2006), even the 'Eisner Era' women are 'devout care-takers of those around them, require the protection ... of a male authority figure ... and live out adventures which are at least sanctioned ... by the patriarchies in which all of the characters live' (p. 219).

Since these works, Disney has released a number of modern princess movies across the late 2000s and 2010s, including specific Disney Princess titles, such as Tangled (2010) and Brave (2012, released under Pixar), as well as those not officially associated but involving central, royal, female characters, including Frozen (2013) and Moana (2016), which have accumulated approximately $\$ 3$ billion in gross global ticket revenue to date (Box Office Mojo 2011, 2013, 2014, 2017). These movies have also enjoyed staggering popularity amongst young girls and increasingly, in the case of Frozen and Moana, young boys worldwide (Gomez 2014; Koonikova 2014). The mainstream media has likewise responded favorably, and a number of articles have argued that these movies contain significantly 
more androgynous princess characters (Pulver 2016), portray a progressive rejection of typical romantic conclusions (Pulver 2016), and present increasingly self-sufficient princesses who take an active role in plot progression (Abersol 2014). The highest level of media praise is afforded to Moana, with many critics identifying a brave heroine with a sense of humor and a commitment to saving the world without romantic distractions (Dunsmore 2017; Duralde 2016; Machado 2016; Ngata 2016; To 2016). Importantly, these releases have taken place against a backdrop of unprecedented political, social and economic advancement for women worldwide, as well as increasing social discourse and acceptance surrounding gender-role flexibility and fluidity (Marsh 2016).

Yet work examining female portrayals in Disney movies released after 2003, particularly from a quantitative perspective, is still surprisingly sparse. England et al. (2011) provided some limited analysis, finding that, in their most recent movie analyzed, The Princess and the Frog (2009), the female character was more egalitarian than those in previous movies. Some qualitative appraisals also exist, which remain critical of newer female characters, for example arguing that women still cannot possess both love and power (e.g., Elsa in Frozen, Dundes et al. 2018; Streiff and Dundes 2017a), and that women are abusive of the power they gain (e.g., Te Kā in Moana, Streiff and Dundes 2017b). However, at present, no study has thoroughly examined gender representations in female characters in Disney movies released after 2003, particularly from a quantitative perspective. This is despite considerable appetite for more research on titles released since the turn of the millennium, as demonstrated by the existence of numerous undergraduate and postgraduate research projects (Garabedian 2014; Hartwell 2015; Lopreore 2016; Saladino 2014), as well as a number of media pieces (Abersol 2014; Pulver 2016) on the subject. Such research is also vital considering concerns expressed regarding the vulnerable nature of young girls absorbing gendered messages from Disney movies (Best and Lowney 2009; Orenstein 2006, 2011; Signorielli 2001), as well as the possible positive implications for gender role development resulting from exposure to more well-rounded characters.

\subsection{Representations of Men}

Even fewer studies have examined the behavior of men in Disney movies, however some appraisals do exist. The work by Towbin et al. (2004) outlined above provides some evidence, finding that male characters were more likely to: use physicality to express their emotions, lack control over their sexual impulses, be naturally strong and heroic, have non-domestic jobs, and, if overweight, have negative characteristics. This suggests that the men in these movies may suffer from similarly traditional and restrictive gender role portrayals as women. Again, whilst examinations on individual movies exist (e.g., of the characters in Hercules, Primo 2018), Davis (2013) provides possibly the most comprehensive qualitative assessment of Disney men up to, and including, those in Wreck-It-Ralph (released in 2012). Men are largely labelled as either 'Dashing Heroes' (e.g., Aladdin in Aladdin, or Flynn Rider/Eugene in Tangled) or 'Handsome Princes' (e.g., Prince Eric in The Little Mermaid or Prince Naveen in The Princess and the Frog), the former characterized by their sense of injustice and their motivation to be their best possible selves for the women they love, the latter characterized by the journeys they must take to earn manhood after a substantial 'fall from grace', and to become true, good men (/princes). Importantly, and in contrast to Towbin et al. (2004), Davis notes that whilst many stereotypically masculine traits are present in these characters, they are often accompanied by typically feminine traits, such as emotional sensitivity (exemplified most clearly in 'Action Men' John Smith and Li Shang from Pocahontas and Mulan respectively).

Other scholars support these more positive assessments of male characters, particularly in movies released in the 1990s and 2000s (such as Pixar titles Toy Story, The Incredibles, and Cars), where men grow to accept their feminine characteristics (Gillam and Wooden 2008). Indeed, quantitative appraisals provide further evidence for very balanced gender profiles in central male characters across Disney Princess movies up to 2009 (England et al. 2011). Thus, whilst some have been critical of male characters in more recent movies (e.g., the hyper-masculinized Maui in Moana, Streiff and Dundes 2017a), it is strongly argued that representations of men do appear to have evolved and matured over time, 
not only in relation to themselves as characters, but in their interactions with, and growing respect for, female protagonists (Davis 2013). Indeed, similar to her observations regarding female characters, Davis concludes that 'Disney's depictions of masculinity are not perfect. But ... they are improving' and that 'The sheer variety and diversity of types of male characters in Disney's animated feature films is continuing to improve, setting up good role models of masculinity for both boys and girls who are watching' (Davis 2013, p. 253). However, in-depth quantitative examination of gender role portrayals by male Disney characters since England et al.'s (2011) study has not yet occurred. This is desperately needed in order to investigate the messages regarding gender which young boys and men receive from such media (Coyne et al. 2016), often overlooked.

\subsection{Rescue Behavior}

Other important gendered messages for young children lie in the themes of heroism and love in Disney movies. Research examining heroism through rescue behavior suggests that, whilst princesses performed an equal amount of rescues to prince characters, they were also significantly more likely to require saving (England et al. 2011). Princesses were also rarely responsible for 'climactic' rescue scenes, in other words the final, most dramatic, and most significant scene of the movie, requiring a central, often male character to save another from a dangerous situation and provide significant plot resolution and the abating of peril (England et al. 2011). Such research agues therefore that princesses are mostly presented as characters who cannot act effectively or independently in important and often life-threatening situations. This may in turn present young children with the message that heroism, and associated concepts such as risk and strength, are inherently masculine, and that women are weak, passive, and in need of assistance.

Some researchers have provided interesting commentary on the heroic actions of specific 1990s princesses, such as Pocahontas, arguing that she presents a stronger type of princess who performs numerous brave behaviors throughout the movie and ultimately saves the lead male character (John Smith) from death by the hand of her father (Dundes 2001). Indeed, the 'Eisner Era' princesses and 'good daughters' described by Davis (2006) demonstrate numerous acts of bravery, including self-sacrifice and physical combat. Moreover, recent media commentary, focused on the releases of Brave, Frozen, and Moana, has further highlighted changes in the presentation of princesses' heroic behavior, specifically their progression from 'passive damsels' to 'active heroes' (Hugel 2013), suggesting that, when it comes to heroism, the reign of men may be over.

\subsection{Romance \& Living 'Happily Ever After'}

The presentation of romantic narratives in Disney movies, and the messages given to children regarding the formation of romantic relationships, has also been subject to scrutiny. For example, Cokely has highlighted the unanimously heterosexual nature of romantic resolutions in Disney movies, as well as their magical, fantastical and unrealistic nature (Cokely 2005; Garlen and Sandlin 2017). Hefner and colleagues (Hefner et al. 2017) further emphasizes that such romantic ideals are consistently rewarded in Disney films, whereas challenges are punished. Other researchers have observed that children are routinely exposed to the social script that "one falls in love either very quickly, at first sight (Snow White, Sleeping Beauty), against all odds (Beauty and the Beast, Mulan, The Princess and the Frog), or both (Cinderella, The Little Mermaid, Aladdin, Pocahontas)" (Davis 2006; England et al. 2011, p. 565). Princesses also rarely remain single at the end of these movies (England et al. 2011), suggesting that finding love is a key goal for any princess (and by extension any young girl/woman).

However, in the two most recent films analyzed by England et al. (2011), Mulan and The Princess and the Frog, the two central characters fell in love over a longer period of time, whilst overcoming obstacles and achieving joint goals. Other scholars support these observations, noting a shift to more well-rounded princess characters with deeper romantic narratives (Davis 2006; Stover 2013). Therefore, whilst some are still critical of developments in the romantic storylines of princesses (such as Elsa's 
replacement of romance with power in Frozen, Streiff and Dundes 2017a), it would appear that most observations of later films are positive in this regard. Thus, examination of both rescue behavior and romantic outcomes in Disney movies released post-2000 is therefore much needed, both to inform and support current media discourse, as well as to explore how such behaviors constitute part of gender portrayal for these characters.

\subsection{The Ubiquity of Disney in the Lives of Young Children}

Such an endeavor is arguably worthwhile considering results from several studies which suggest that the gendered content presented by Disney is enthusiastically incorporated into the narratives and interactions of young girls, fueled by the pervasiveness of Disney content in children's lives (Giroux and Pollock 2010). For example, both Baker-Sperry (2007) and Wohlwend (2009) found that young girls in kindergarten and 1st grade who identified as avid fans of Disney took up familiar princess narratives in their writing and pretend play, fiercely correcting divergent interpretations by peers. Moreover, Golden and Jacoby (2017) identified four themes emergent during 3- to 5-year-old girls' Disney-themed pretend play and discussions: a focus on clothing and accessories, beauty, princess body movements, and exclusion of boys. Such topics demonstrate that traditionally limited gender representations offered in princess characters are emphatically adopted into a young girl's gender schemas and scripts. An observation further supported by the limited quantitative research available, which demonstrates that engagement with Disney Princess media/products is predictive of increased gender stereotypic behavior 1 year later (Coyne et al. 2016).

Such research supports the notion that media such as Disney movies may be specifically designed and produced to be consumed through a gendered lens, and that such media forms are constructed in a way to directly appeal to children in this way (Oliver and Green 2001). These observations have important implications, principally that young girls viewing visual media with restrictive and limiting female gender role portrayals, such as Disney movies, may adopt such representations for themselves. This is not to say that an increased performance of feminine behaviors in response to such media is problematic in its own right, as acknowledged by Coyne et al. (2016). Instead, the transmission of presentations of women that may serve to restrict their behavior and choices is cause for serious concern. Such issues exist regarding media consumption by young male viewers also, though they garner significantly less attention both academically and in the popular press (Streiff and Dundes 2017a).

This makes the identification of more positive gender role portrayals all the more pressing, as the existence of popular media forms which seek to remove and challenge restrictive stereotypes may, by direct contrast, have more positive and liberating effects on children's understandings of gender norms and stereotypes. Indeed, some studies already demonstrate that young girls adapt existing princess narratives in response to social limitations in princess identities and behavior, revising character qualities and storylines to form counter narratives of their own that are more representative of them as individuals and are less restrictive (Wohlwend 2009). Moreover, recent research has shown that young viewers are aware of the changing gender-role portrayals of princesses (in that they identify princesses such as Moana as more balanced in their portrayal of masculine and feminine characteristics than Aurora from Sleeping Beauty, Hine et al. 2018). However, a more comprehensive investigation of gender portrayals in movies released after the year 2000 remains absent.

\subsection{The Present Study}

As outlined above, a number of theories suggest that gender role representations within the media, including those within the world of Disney (Coyne et al. 2016; Wohlwend 2009), play an important and dynamic role in shaping young children's conceptualizations of gender (Graves 1999; Martin et al. 2002). Therefore, considering the Walt Disney Company's continued and considerable commercial success (The Walt Disney Company 2017); the widespread access to Disney films afforded to children of all ages; the popularity of Disney movies featuring princess characters in particular (Davis 2006, 2013); and the iconic nature of the characters presented therein (Orenstein 2006), it is 
reasoned that investigating gender role representations within this franchise is a worthwhile pursuit. Furthermore, to examine gender role portrayals in more recent Disney titles is argued to be particularly important when considering the significant role media forms play in both shaping and representing social change (Eagly 2013). This is emphasized, for example, by the Walt Disney Company's own acknowledgement of, and contribution towards, discourse surrounding female empowerment in the launching of its \#DreamBigPrincess campaign to support the aspirations of young girls worldwide (The Walt Disney Company 2016).

The present study therefore examined the gendered behavior of prince and princess characters, as well as rescue behavior and romantic conclusions, in five "2000s to 2010s" Disney movies: The Princess and the Frog (2009), Tangled (2010), Brave (2012, released under Pixar), Frozen (2013), and Moana (2016), and compared these to the eight older titles previously analyzed in England et al. (2011). There were four hypotheses:

Hypotheses 1 (H1A). Prince and Princess Characteristics: We predicted that both princes and princesses in movies released in the 2000s to 2010s would have androgynous behavioral profiles (i.e., they would display an equal number of masculine and feminine characteristics), both when examined for princes and princesses individually (e.g., the princess character shows masculine and feminine characteristics with equal frequency) and in comparing princes and princesses (e.g., the princess character portrays as many masculine characteristics as the prince counterpart).

Hypotheses 1 (H1B). Differences in Gender Expression over Time: We also predicted that the gendered behavior exhibited by princesses, but not princes, would have changed historically (i.e., from "1930s to 1950s" to "2000s to 2010s" movies). Namely, whilst princes would maintain an androgynous expression of behavior across time (e.g., show a similar number of masculine behaviors in "2000s to 2010s" compared to earlier movies), princesses would change from displaying mostly feminine behaviors in "1930s to 1950s" movies to more androgynous patterns in "2000s to 2010s" movies.

Hypotheses 2. Rescue Behavior: Our third hypothesis predicted that rescue behavior in "2000s to 2010s" movies would also be more egalitarian, both when examined for princes and princesses individually (e.g., the princess character performs rescues with similar frequency to being rescued) and in comparing princes and princesses (e.g., the princess character performs as many rescues as the prince counterpart).

Hypotheses 3. Romantic Outcomes: The final hypothesis predicted changes in romantic outcome across time, specifically that princesses in "2000s to 2010s" movies would be less likely to marry or 'live happily ever after' with the prince than those in earlier movies.

\section{Results}

\subsection{Hypothesis $1 A$-Prince and Princess Characteristics}

Two same sample $t$-tests were conducted to assess whether the percentage of masculine behavior shown by all princes and princesses across "2000s to 2010s" movies were significantly different to a value of $50 \%$ (i.e., the percentage that would represent an exactly equal split between masculine and feminine behavior). Only masculine behaviors were assessed as values representing the percentage of feminine behaviors provide the corresponding values and would mirror results. The masculine behavior percentage for princesses was not significantly different to $50 \%$, suggesting that both masculine $(52.6 \%)$ and feminine behaviors $(47.7 \%)$ accounted for close to half of overall princess behavior. Conversely, the masculine behavior percentage for princes was found to be significantly different to $50 \%, \mathrm{t}(3)=4.87, p<0.05$, suggesting that princes' masculine behavior constituted significantly less than half of their overall behavior (38.5\%), with feminine behavior comprising significantly more $(61.5 \%)$. Broadly, these results suggest that both masculine and feminine attributes are highly valued, and frequently exhibited by female central characters, thus capturing a clear 
representation of androgyny (Bem 1974, 1975). Central male characters, however, show a less balanced behavioral profile, exhibiting more feminine behaviors overall.

An independent sample $t$-test was conducted to compare the overall expression of masculine characteristics of princes versus princesses. Again, only masculine percentages were examined as feminine percentages comprise corresponding values, producing mirrored results. Results showed that princess characters exhibited significantly more masculine characteristics $(M=52.6, S D=7.98)$ than princes $(\mathrm{M}=38.5, \mathrm{SD}=4.73), \mathrm{t}(7)=3.09, p<0.05$. This also demonstrates that princes showed more feminine characteristics overall (61.5\%) than princesses (47.4\%). Examining the top five most frequently displayed behaviors by prince and princess characters in each movie provides further detail, as several shared characteristics are identified. In The Princess and the Frog, the prince and princess shared "affectionate", "athletic" and "assertive" in their top five characteristics; in Tangled and Frozen they shared "athletic", "fearful" and "assertive"; and in Brave they shared "athletic" and "assertive". "Athletic" and "assertive" were therefore in the top five characteristics for both princes and princesses in all "2000s to 2010s" movies with both characters, and characteristics relating to affection and fear were shared by both princes and princesses in three of the movies. This shows that, whilst princesses are shown to be more masculine, and less feminine, than princes overall, when examining the most frequent behaviors, similar masculine and feminine characteristics were valued and expressed by central characters of both genders (See Table 1).

Table 1. Most frequent traits in for princes and princesses in the five "2000s to 2010s" movies.

\begin{tabular}{|c|c|c|c|c|c|}
\hline Prince Trait & Tallies & $\%$ Total Behavior & Princess Trait & Tallies & \% Total Behavior \\
\hline Shows emotion & 268 & 24.36 & Assertive & 282 & 13.43 \\
\hline Athletic & 137 & 12.45 & Athletic & 269 & 12.81 \\
\hline Assertive & 102 & 9.27 & Fearful & 211 & 10.05 \\
\hline Fearful & 97 & 8.82 & Tentative & 167 & 7.95 \\
\hline Victim & 62 & 5.64 & Physically strong & 127 & 6.05 \\
\hline Affectionate & 61 & 5.55 & Affectionate & 121 & 5.76 \\
\hline Physically strong & 50 & 4.55 & Wants to explore & 82 & 3.90 \\
\hline Tentative & 36 & 3.27 & Submissive & 71 & 3.38 \\
\hline Unemotional & 36 & 3.27 & Brave & 68 & 3.24 \\
\hline Curious ab. Princess & 36 & 3.27 & Troublesome & 68 & 3.24 \\
\hline Submissive & 32 & 2.91 & Intellectual activity & 56 & 2.67 \\
\hline Troublesome & 28 & 2.55 & Independent & 54 & 2.57 \\
\hline Helpful & 26 & 2.36 & Asks for advice/help & 52 & 2.48 \\
\hline Physically weak & 17 & 1.55 & Inspires fear & 46 & 2.19 \\
\hline Gives advice & 17 & 1.55 & Unemotional & 46 & 2.19 \\
\hline Inspires fear & 14 & 1.27 & Victim & 46 & 2.19 \\
\hline Asks for advice/help & 10 & 0.91 & Helpful & 44 & 2.10 \\
\hline Leader & 9 & 0.82 & Leader & 44 & 2.10 \\
\hline Gets rescued & 9 & 0.82 & Ashamed & 43 & 2.05 \\
\hline Wants to explore & 7 & 0.64 & Nurturing & 37 & 1.76 \\
\hline Brave & 7 & 0.64 & Physically weak & 30 & 1.43 \\
\hline Sensitive & 7 & 0.64 & Gives advice & 28 & 1.33 \\
\hline Intellectual activity & 6 & 0.55 & Performs rescue & 23 & 1.10 \\
\hline Descr. as attractive & 6 & 0.55 & Sensitive & 22 & 1.05 \\
\hline Performs rescue & 6 & 0.55 & Gets rescued & 21 & 1.00 \\
\hline Nurturing & 5 & 0.46 & Tends to phys. app. & 18 & 0.86 \\
\hline Tends to phys. app. & 4 & 0.37 & Descr. as attractive & 15 & 0.71 \\
\hline Ashamed & 3 & 0.27 & Collapses crying & 13 & 0.62 \\
\hline Independent & 2 & 0.18 & & & \\
\hline Collapses crying & 0 & 0.00 & & & \\
\hline
\end{tabular}

\subsection{Hypothesis 1B-Differences in Gender Expression over Time}

One-way ANOVAs were conducted to test the effects of the chronological grouping of movies on the gendered characteristics observed, one using data for princes and another for princesses. 
This involved comparing data newly generated in this study on "2000s to 2010s" movies with data generated by England et al. (2011) for older titles. Again, only the values for percentage of masculine behaviors were used. For prince characters, a borderline significance was found $(p=0.09)$, suggesting that the percentage of masculine characteristics exhibited by princes has changed modestly over time. Examining these patterns more closely, it appears that prince characters were lower on masculine characteristics in "1930s to $1950 \mathrm{~s}$ " $(\mathrm{M}=45.33, \mathrm{SD}=14.15)$ and "2000s to $2010 \mathrm{~s}$ " movies $(\mathrm{M}=38.5$, $\mathrm{SD}=4.73)$ than in "1980s to $1990 \mathrm{~s}$ " movies $(\mathrm{M}=59.2, \mathrm{SD}=15.55)$. In contrast, princess characters have experienced a clear and significant change in their performance of gendered behavior across time, with the proportion of masculine characteristics increasing significantly, F $(2,12)=43.99, p<0.001$. Post hoc tests using Tukey's HSD revealed significant differences between "1930s to 1950s" and "1980s to 1990s", $p<0.001$, and "1930s to 1950s" and "2000s to 2010s" movies, $p<0.001$, as well as "1980s to 1990s" and "2000s to 2010s" movies, $p<0.05$. These results therefore suggest that, whilst prince characters have once again become more feminine in their behavior, princesses have become progressively more androgynous over time, demonstrating the most balanced behavioral profiles in "2000s to 2010s" movies.

\subsection{Hypothesis 2-Rescue Behavior}

Paired sample $t$-tests were conducted to investigate the performance of rescue behaviors by prince and princess characters in "2000s to 2010s" movies respectively, with results demonstrating no significant differences in characters' performance of rescues and their instances of being rescued. In addition, independent-samples $t$-tests compared the total number of rescue behaviors by princes and princesses. No significant differences were found for either being rescued, or performing rescues, suggesting that prince and princess characters performed these behaviors with equal frequency. These results suggest that prince and princess characters are very similar in their demonstration of rescue behaviors in "2000s to 2010s" movies. Interestingly, princesses in these movies took a greater role in climactic rescue scenes, as well as engaging in more collaborative problem-solving with the prince, than in earlier films. A more detailed examination of rescue behavior by both prince and princess characters is included in the discussion.

\subsection{Hypothesis 3-Romantic Outcomes}

A chi-square test of independence was performed on the romantic outcomes codes for all movies to examine the relationship between movie era and romantic outcome. The relationship between these variables was significant, $\chi^{2}(2, \mathrm{~N}=13)=6.24, p<0.05$, with results showing that princess characters in "2000s to 2010s" movies were less likely to end up married and/or living happily ever after than princesses in "1930s to 1950s" or "1980s to 1990s" movies who almost unanimously conformed to this outcome. "2000s to 2010s" Disney Princess movies therefore represent a significant sea change in the presentation of romantic narratives. Specifically, whilst the princesses in The Princess and the Frog and Tangled do indeed marry the prince, Brave, Frozen and Moana take a significant departure from this pattern. Neither Merida nor Elsa (Brave and Frozen, respectively), are shown to be significantly romantically involved, married to or as living happily ever after with a prince character at the conclusion of the movie. Moana contains no romantic narrative at all. These patterns suggest Disney is becoming less rigid in their presentation of romantic storylines, occasionally even foregoing this plot line completely.

\section{Discussion}

"I am Moana of Motunui. Aboard my boat $I$ will sail across the sea and restore the heart of Te Fiti" - Moana, after 'I am Moana (Song of the Ancestors)'

As proposed, this study examined the expression of gendered characteristics by the central prince and princess characters in five "2000s to 2010s" Disney movies-The Princess and the Frog, Tangled, 
Brave (released under Pixar), Frozen, and Moana. Changes in the frequency of masculine and feminine characteristics exhibited by prince and princess characters over time were also assessed, as was the frequency of rescue behavior and romantic outcomes. This is the first study to quantitatively document the behavior of prince and princess characters in Disney movies released post-2009, and to compare them to previous Disney titles featuring princess characters. Results showed that princess characters in "2000s to 2010s" movies exhibit an androgynous pattern of behavior, particularly in comparison to their historical counterparts. Interesting patterns also emerged for prince characters, as a traditionally androgynous profile became increasingly feminine. Results also suggest that prince and princess characters in "2000s to 2010s" movies participate equally in important rescue behaviors, and that traditional romantic trajectories have changed to include non-romantic outcomes.

\subsection{The Rise of the Androgynous Princess}

Hypothesis 1A was generally supported, as princess characters in "2000s to 2010s" movies exhibited a similar amount of masculine and feminine behaviors. This supports previous research (England et al. 2011), as well as articles from the popular press (Abersol 2014; Pulver 2016), suggesting that princesses in "2000s to 2010s" Disney movies exhibit more balanced, or androgynous behavioral profiles. This is further reflected in the behaviors most frequently exhibited by princess characters, where traits such as being "athletic" and "assertive" sat beside "fearful" and "tentative". Indeed, the behavioral makeup of princesses in "2000s to 2010s" movies is markedly different from the traditional, gender-typical profiles seen in earlier titles (Davis 2006; England et al. 2011; Towbin et al. 2004). Results therefore also supported hypothesis 1B, as princesses were found to be less feminine and more balanced in their behavioral profiles over time.

In other words, the largely passive behavior of older princesses such as Snow White and Cinderella (Davis 2006) have been replaced by the active, strong, and independent characters of Merida and Moana. These findings reflect children's own awareness of the changing behavioral profiles of princess characters (Hine et al. 2018), and support suggestions by the press that popular media sources, including Disney, may be starting to provide positive and behaviorally balanced role models, such as Moana, for young girls (Dunsmore 2017; Duralde 2016; Machado 2016; Ngata 2016; To 2016). Such results are consistent with patterns of social change proposed by Social Role Theory (Eagly 2013), as the new gender profiles seen in "2000s to 2010s" Disney movies both reflect and subsequently shape the changing role and increased freedom of women and girls in Western society (Marsh 2016). This change is particularly important considering the numerous theories which highlight the importance of such models within the environment for gender identity formation (for example, Gender Schema Theory, Martin and Halverson 1981), and the suggested positive implications for the socio-emotional wellbeing of young girls of observing such models (Hine et al. 2018).

\subsection{The Changing Prince}

In contrast, prince characters had largely unbalanced profiles in "2000s to 2010s" movies, exhibiting greater amounts of feminine than masculine behavior across all titles. This is unsurprising considering that feminine behaviors such as "Shows Emotion", "Fearful" and being a "Victim", were some of the most frequently exhibited characteristics (accounting for approximately $39 \%$ of their behavior). Princes were also shown to be significantly less masculine, and more feminine, than princess characters, and had intriguing patterns of change over time (with both "1930s to 1950s" and "2000s to 2010s" princes demonstrating more feminine profiles than "1980s to 1990s" princes, although these results were not significant). Such results therefore suggest that, whilst England et al.'s characterization of prince characters as largely androgynous is broadly supported in this study, clear trends towards a more feminine behavioral profile exist. In other words, the largely absent, passive princes of the 1930s and 1950s, and the muscular, brave heroes of the 1980s and 1990s appear to have been succeeded by a troop of sensitive, fearful, but dashing men in the 21st century, thus supporting the argument that the men of Disney are complicated, to say the least. 
Previous work has argued that it is important and valuable to show both women and men as capable of expressing both masculine and feminine characteristics (Bem 1975), and the positive implications for children's gender identity development, and associated psychosocial outcomes, are clear (Martin et al. 2016). However, the higher proportion of feminine behavior by prince characters is certainly no reflection of any obvious role change for men and young boys in society, or greater acceptance of men's feminine interests, as numerous studies suggest they are still consistently and firmly guided away from such pursuits (e.g., playing with feminine toys, see Kollmayer et al. 2018). The reasons behind more feminine behavior in princes are therefore unclear. One explanation is that Disney seeks to discourage feminine behavior in young boys, and thus reinforce broader societal norms, by presenting these characteristics in a negative light. For example, whilst the valence of the behaviors was not directly assessed in this study, negative or overly-dramatic portrayals of "fearful" or "tentative" traits (for example, as demonstrated by Prince Naveen throughout The Princess and the Frog), or of being overly "affectionate" or "sensitive" (exemplified by characters like Kristoff in Frozen) may seek to discourage young boys from adopting such behaviors. This explanation would fit well with post-feminist interpretations of masculinity within popular media forms, including Disney movies (Macaluso 2018), which seek to present men "as somewhat hapless, bumbling 'victims' or 'losers' in the 'sex wars'" (Gill 2014), and with arguments centered around the reinforcement of hegemonic masculinity through the demonization of feminine traits and attributes, particularly when performed by men (Connell 2005).

Alternatively, rather than mocking gender atypicality in men, it is possible that Disney is instead acting as a catalyst for a dissection and re-evaluation of masculinity, and the strict gender norms imposed upon young boys and men. This is the explanation offered by both Davis (2013) and Coyne and colleagues (Coyne et al. 2016), who propose that Disney films may actually offer important models of feminine behavior for boys amongst a plethora of hyper-masculine messages present in child and adult media (Brown et al. 2009). For example, stoicism (emotional restraint) is traditionally regarded as an important and idealized masculine trait (Donaldson 1993), and yet "Shows emotion" accounted for almost a quarter of prince behavior in "2000s to 2010s" movies. Clearly such behaviors are therefore important to princes, as they form such a large proportion of their interactions. Further, one need only look to the 'I've got a dream' scene in Tangled (35:50-40:46) to see big, burly, aggressive vigilante men sing, openly and positively, about the largely feminine dreams and interests they hold. Perhaps Disney is simply reflecting that traditional constructions of masculinity are under increasing scrutiny, as the requirements of a traditional male gender role in the modern world are questioned (John 2002). Whatever the motivation behind such portrayals may indeed be, continued analysis of Disney masculinity is clearly warranted.

\subsection{New Hero(ine)s}

Hypothesis 2 was also supported, in that both prince and princess characters performed rescues, and were themselves rescued, with similar frequency. In addition, princesses performed as many rescues, and were also rescued as often as princes. This expands upon the work of England and colleagues (2011) which showed that later princesses performed rescues equally as often as princes, and challenges traditional observations that princesses are more likely to end up as 'damsels in distress'. Moreover, and in contrast to earlier movies, princesses played an increasingly key role in climactic rescue scenes. For example, instead of scenes exemplified by 1930s and 1950s princesses such as Snow White and Aurora, who require saving by the central male character from some precarious scenario, these situations have begun to involve either the prince and princesses working together (such as in Tangled, where, within the same scene, Flynn saves Rapunzel from a life of servitude by cutting her hair, and Rapunzel saves Flynn by using her tears to heal his fatal wound), or princesses performing the climactic rescue act solo (such as in Brave, when Merida sews together the ripped tapestry to save her mother from the witch's spell). "2000s to 2010s" princesses also increasingly shared responsibility with prince characters in other scenes of jeopardy, as a hero(ine) who can bring, or help bring about 
a resolution (such as in Frozen, where Anna and Kristoff work together to fend off an pursuing wolf pack), instead of simply being a passive recipient of help. Importantly, they perform this role both by suggesting ideas and by contributing physically. Princesses in these movies also frequently engaged in 'self-saving', rather than relying on the prince to perform the rescue. Results from this study therefore support observations in the popular media that princesses are increasingly portrayed as independent, self-reliant, competent, active and brave characters, who are fundamentally important to the resolution of situations containing misfortune, peril, and mortal danger (Abersol 2014).

\subsection{Remaining Single and Saving the World}

Hypothesis 3 was also supported, as princess characters in "2000s to 2010s" movies were significantly less likely to end up married or living happily ever after than in "1930s to 1950s" or "1980s to 1990s" movies. This study therefore furthers initial observations of "1980s to 1990s" movies that characters were starting to fall in love over longer periods of time (England et al. 2011), and suggests that, for some characters, love is no longer a priority. For example, whilst Tiana and Rapunzel (in The Princess and the Frog and Tangled respectively) are still presented as married at the end of their movies, this was neither of their initial goals. Instead, both end up realizing through interacting with those male counterparts that they may be interested in a romantic involvement and subsequently fall in love. This is significantly different from the already less extreme romantic narratives presented in "1980s to 1990s" movies where princes and princesses may spend more time together but are still willing to make great personal sacrifices to achieve true love (for example, in The Little Mermaid).

Brave, Frozen and Moana present a more significant departure from the traditional romantic narrative offered in Disney (and Pixar) movies, as these characters were coded as 'single' at the end of their movies. This suggests that finding love is no longer presented as a key endeavor or foregone conclusion (a phenomenon arguably started in some 1990s princesses, Davis 2006), and devices utilized in both Brave and Frozen serve to parody and even ridicule traditional romantic narratives (e.g., Merida fighting for her own hand in marriage, and the presentation of Anna's desire to marry a man she has just met as ridiculous). The greatest exemplification of this shift is found in Moana, where no romantic narrative is offered at all. This is a stark contrast to the love-at-first-sight narratives presented in "1930s to 1950s" movies, where princesses meet or awake to their prince charming and live happily ever after with them (Davis 2006). Indeed, the presentation of alternative romantic conclusions is particularly ground-breaking for a company that has presented traditional hetero-romantic messages for nearly a century. Such changes are especially important considering the impact that romantic scripts in media have on children's understanding of relationship formation and maintenance (Holmes 2007; Morr-Serewicz and Gale 2008), as well as the expression of sexual desire within relationships (Eggermont 2006).

\subsection{Limitations and Future Research Directions}

There are, however, a number of methodological limitations to this study. First, this study used a strictly quantitative approach for the coding and analysis of these movies. There is much to be gained from this methodology, particularly in understanding the frequency of behavior and how this changes over time, the categorical outcomes of these movies, and the balance of masculine versus feminine behavior by princes and princesses. However, further qualitative or novel mixed-methods approaches to analyzing "2000s to 2010s" Disney movies are still necessary to provide a richer understanding of the behavioral profiles of characters, particularly with regards to the negative versus positive valence of behaviors, as well as the circumstances in which behaviors are performed. Future studies should seek to employ a variety of methods in order to fully understand the gendered messages presented by central characters in these movies.

A second methodological limitation of this study is the coding system utilized. The codes employed in this study were consistent with the research upon which this study expands (England et al. 2011), and achieved high inter-rater reliability scores. However, some codes may 
not capture the richness of behavior exhibited. For example, the "Shows Emotion" code for princes was important in the original scheme, as, princes in "1930s to 1950s" and "1980s to 1990s" movies did not exhibit enough emotional behavior for this to be separated into distinct acts (as it is for princess characters). However, the high proportion of emotional behavior shown by princes in "2000s to 2010s" movies suggests that summing all emotional behaviors of male characters is no longer appropriate, and demonstrates that future studies should consider revision to the coding scheme. That being said, it was important to maintain for this study to highlight the change and allow for direct comparison.

It is also worth noting that the very notions of "femininity" and "masculinity" are subject to changing political, historical and cultural norms and discourse. Particularly relevant for this study is the emergence of a so-called 'Fourth Wave' of Feminism from around 2008 (Baumgardner 2011), after the original coding of England et al. (2011) but before the coding for the current study took place, and the subsequent gender discourse that this new, technology-enhanced feminism stimulated. It is quite possible, even probable, that some of the behaviors classified as "feminine" or "masculine" within this study no longer carry such distinct labels, or indeed neatly fit into one category or the other. For the purposes of this study, and in order to enable direct comparison with previous literature and the conclusions therein, an identical coding system was utilized. However, future research should seek to construct coding frameworks using the most up-to-date and appropriate definitions of behavior, possibly informed by how, or even if, young viewers categorize behaviors coded in such a way.

A third limitation is represented by the decision to focus exclusively on Disney movies involving prince and princess characters. Indeed, other popular Disney and Pixar movies exist across the time frame chosen for this study (e.g., Toy Story 3, released in 2010, Wreck-It-Ralph, released in 2012, and Big Hero 6, released in 2014) and beyond (e.g., Coco, released in 2017 and The Incredibles 2, released in 2018), and examining the behavioral profiles of male and female characters within these movies may prove worthwhile. It is also worth noting that even within these two production houses, differences in managerial style, company history and creative focus may influence representations of gender within work produced (Davis 2006). Moreover, analyzing the behaviors of secondary characters within such movies, both independently and in contrast to principles, may also provide rich material for furthering our understanding of gender representations. Examination of villainous characters, and the possible use of gender-atypicality to exemplify villainy (Li-Vollmer and LaPointe 2003; Ramadan 2015), is also worthy of future exploration.

A particularly important avenue for research is the assessment of the impact of these gendered messages on young children. Whilst preliminary evidence suggests that greater engagement with the Disney Princess franchise as a whole results in increased feminine behavior by both young girls and boys (Coyne et al. 2016), at present no research has examined the impact of movies from different Disney 'eras' on the gendered beliefs and identities of young children. The specific impact of modern, androgynous gender-representations in princess characters on the gender identity development of young girls is therefore yet to be fully assessed. In addition, considering the increased feminine behavior by male characters in "2000s to 2010s" movies, the investigation of young boys' engagement with both prince and princess characters in Disney movies, as well as the impact of such media on young boys' gender role development, is an important focus for future investigation.

\subsection{Conclusions}

Several popular press articles have suggested that princess characters in "2000s to 2010s" Disney Princess movies have become more androgynous and balanced in their expression of masculine and feminine behavior. This study aimed to empirically assess these observations, finding not only that princesses were largely androgynous in their behavioral profiles, but that they are increasingly instrumental in the resolution of dangerous situations, and are no longer restricted to traditional romantic resolutions. Interesting results regarding the increasingly feminine behavior of prince characters were also found, and both are worthy of further investigation. Importantly, the arguments presented in this paper strongly suggest that these "2000s to 2010s" movies could have a significant 
impact on the socialization of gender in young children, possibly promoting healthier and more inclusive attitudes regarding gender and gendered behavior.

However, these messages should be interpreted with caution, as a number of concerns with Disney movies still exist which are not specifically addressed in this study, such as negative presentations of body image (Baker-Sperry and Grauerholz 2003; Griffin 2000; Northup and Liebler 2010; Towbin et al. 2004) and race (Cheu 2013; Foote 2010; Gregory 2010) to name a few. Furthermore, Disney is yet to enter into the arena of non-heteronormative relationships, despite the increasingly open discourse surrounding sexuality in society. It is therefore still vitally important, despite the indication of more positive representations suggested by this study, for parents to both encourage and engage in critical consumption of Disney movies (particularly older titles) in order to challenge more traditional gender stereotypes and messages, and to promote a healthy dialogue with children around gender (Coyne et al. 2016). At present however, Disney does appear to have taken significant, important and much welcomed steps towards a more positive and balanced presentation of both male and female central characters in Disney movies, in line with cultural advances in gender role flexibility.

\section{Materials and Methods}

Content coding analysis was utilized to identify and record gendered characteristics in five Disney/Pixar movies released across the 2000s and 2010s featuring human, royal, female characters, typically princesses: The Princess and the Frog, Tangled, Brave, Frozen and Moana. These films were chosen using the following parameters, in that they: (a) were produced and distributed by Walt Disney Animation Studios or Pixar Animation Studios after the year 2000, (b) feature a princess specifically from the Disney Princess line (in the case of The Princess and the Frog, Tangled, and Brave), or a royal female character, typically a princess (in the case of Frozen and Moana), and (c) had achieved more than $\$ 200$ million in box office takings worldwide. This provided movies that had both popular central characters for analysis and had enjoyed substantial international financial success. Table 2 provides an overview of the characters coded in each movie, along with their categorization as princes/princesses, and thus reason for selection. For the purposes of this study, due to the overwhelming majority of characters being clearly classified as princes or princess by either birth or marriage, and due to both the popular media and children's recognition of almost all of the central female characters below as princesses (Hine et al. 2018), these characters will be referred to as princes and princesses throughout.

Table 2. An Overview of Characters Selected for Coding in each Target Movie and their Justification for Inclusion.

\begin{tabular}{ccccc}
\hline Movie & $\begin{array}{c}\text { Princess } \\
\text { Characters }\end{array}$ & Categorization & Prince Characters & Categorization \\
\hline $\begin{array}{c}\text { The Princess } \\
\text { and the Frog }\end{array}$ & Tiana & $\begin{array}{c}\text { Princess by Marriage \& } \\
\text { Official Disney Princess }\end{array}$ & Naveen & Prince by Birth \\
\hline Tangled & Rapunzel & $\begin{array}{c}\text { Princess by Birth \& } \\
\text { Official Disney Princess }\end{array}$ & $\begin{array}{c}\text { Eugene/Flynn } \\
\text { Rider }\end{array}$ & Prince by Marriage \\
\hline Brave & Merida & $\begin{array}{c}\text { Princess by Birth \& } \\
\text { Official Disney Princess }\end{array}$ & $\begin{array}{c}\text { Wee Dingwall } \\
\text { Young Macintosh }\end{array}$ & $\begin{array}{c}\text { Prince by Birth } \\
\text { Prince by Birth } \\
\text { Prince by Birth }\end{array}$ \\
\hline Frozen & Anna & $\begin{array}{c}\text { Princess by Birth } \\
\text { Princess by Birth (then } \\
\text { Queen) }\end{array}$ & $\begin{array}{c}\text { Hans } \\
\text { Christoph }\end{array}$ & $\begin{array}{c}\text { Prince by Birth } \\
\text { linked to Anna }\end{array}$ \\
\hline Moana & Moana & Daughter of the Chief & None Chosen & N/A \\
\hline
\end{tabular}

This "2000s to 2010s" group of movies was also compared to eight previously coded Disney Princess films (England et al. 2011, see Table 3 for chronological groupings). Such an approach (i.e., applying a previously established coding system to new media, and conducting comparative statistical 
analysis on the 'old' and 'new' data) is substantially supported (Krippendorf 2004; Macnamara 2005; Neuendorf 2002; Riff et al. 2014). It is important to note that The Princess and the Frog, whilst originally coded in England et al. (2011), was recoded for this study. This decision was taken to provide clarity within the analysis (i.e., with a distinctly coded group of "2000s to 2010s" movies being compared to previously coded older titles), and because The Princess and the Frog formed an important part of the new conceptual grouping explored within this study.

The coding framework was identical to that used by England and colleagues (2011) in order to facilitate direct comparisons among all movies, and the items within this framework have been recognized as useful and valid in previous research (Thompson and Zerbinos 1995; Towbin et al. 2004). The full coding scheme utilized in this study is outlined in Table A1, and characteristics were determined as masculine or feminine based on prior content analysis research for gender portrayal (Thompson and Zerbinos 1995; see England et al. 2011 for full review). Prince and princess characters were assessed for both the masculine and feminine traits and a code was assigned for each characteristic or behavior based on the following criteria: (a) whenever the observed prince/princess exhibited the characteristic, (b) when another character described the prince/princess as possessing the characteristic, (c) when the characteristic occurred for more than $3 \mathrm{~s}$ (i.e., in rare instances when a characteristic was exhibited for longer than $3 \mathrm{~s}$, it was tallied once per $3 \mathrm{~s}$ demonstration), (d) when the prince/princess performed a characteristic behavior (e.g., tending to his/her physical appearance) and the screen's image changed briefly but then returned to the character, who continued to perform that same act (i.e., this would receive two tallies for that code). The five "2000s to 2010s" movies were also coded for instances of rescuing conducted by the prince and princess characters, as well as the number of times they were rescued, with qualitative observations noted for climactic rescue(s) that occurred at the end of the movie. In addition, all movies, including those originally utilized in England et al. (2011), were coded categorically for the romantic resolution of the movie, namely whether the prince and princess had significant romantic involvement, marriage or the suggestion of 'happily ever after' (1), or whether the princess was single (0).

Table 3. Total Codes and Percentage of Total Behavior Coded as Masculine in Princes and Princesses across "1930s to 1950s", "1980s to 1990s" and "2000s to 2010s" Princess Movies.

\begin{tabular}{|c|c|c|c|c|c|c|c|}
\hline & & & Prince & & & Princess & \\
\hline Movie & Year & $\begin{array}{l}\text { Total } \\
\text { Codes }\end{array}$ & $\begin{array}{l}\% \text { Masculine } \\
\text { Characteristics }\end{array}$ & $M$ & $\begin{array}{l}\text { Total } \\
\text { Codes }\end{array}$ & $\begin{array}{l}\text { \% Masculine } \\
\text { Characteristics }\end{array}$ & $M$ \\
\hline "1930s to $1950 \mathrm{~s} "$ & & & & 45 & & & 13 \\
\hline Snow White & 1937 & 22 & 54 & & 150 & 9 & \\
\hline Cinderella & 1950 & 7 & 29 & & 229 & 18 & \\
\hline Sleeping Beauty & 1959 & 111 & 53 & & 86 & 12 & \\
\hline "1980s to $1990 s "$ & & & & 59 & & & 42 \\
\hline The Little Mermaid & 1989 & 130 & 60 & & 262 & 39 & \\
\hline Beauty and the Beast & 1991 & 85 & 64 & & 164 & 47 & \\
\hline Aladdin & 1992 & 172 & 37 & & 127 & 39 & \\
\hline Pocahontas & 1995 & 212 & 55 & & 235 & 45 & \\
\hline Mulan & 1998 & 61 & 80 & & 208 & 42 & \\
\hline “2000s to 2010s" & & & & 39 & & & 53 \\
\hline $\begin{array}{l}\text { The Princess and the } \\
\text { Frog }\end{array}$ & 2009 & 189 & 32 & & 174 & 47 & \\
\hline Tangled & 2010 & 447 & 42 & & 474 & 44 & \\
\hline \multirow[t]{3}{*}{ Brave } & 2012 & 14 & 36 & & 309 & 62 & \\
\hline & & 16 & 44 & & & & \\
\hline & & 12 & 33 & & & & \\
\hline \multirow[t]{2}{*}{ Frozen } & 2013 & 286 & 41 & & 279 & 48 & \\
\hline & & 136 & 43 & & 183 & 52 & \\
\hline Moana & 2016 & & & & 685 & 60 & \\
\hline
\end{tabular}


Three undergraduate research assistants were intensively trained by the first and second authors of this study on how to use the coding system, using Disney movies that were not part of the current study. Disney movies were utilized to ensure that coders were familiar with the style of animation employed in such films, including how characters engage in particular behaviors. Lead and undergraduate coders then completed coding separately for the first ten minutes of the four target movies coded in this study. After the lead and undergraduate coder had completed coding this ten-minute segment for princess characteristics, inter-coder reliability analysis was conducted using Krippendorff's alpha (KALPHA, Krippendorf 2004) to compare the frequency of codes for each behavior (shown in Appendix A). Values ranged from 0.78 to 0.99 suggesting very high inter-coder reliability across all characteristics. In addition, KALPHA values for each movie (across all behaviors) were computed, with values of 0.97 (The Princess and the Frog), 0.94 (Tangled), 0.99 (Brave), 0.97 (Frozen), and 0.99 (Moana), demonstrating high inter-coder reliability. Any significant discrepancies that arose were examined and reviewed until agreement was reached on how to code future instances of said behaviors. Satisfied with high reliability values and resolution of inconsistencies, undergraduate coders then coded the remainder of each target movie.

Author Contributions: Conceptualization, B.H. and D.E.; methodology, D.E. and K.L.; formal analysis, B.H. and D.E.; investigation, B.H., D.E. and K.L.; resources, E.S. and L.H.; data curation, B.H. and K.L.; writing—original draft preparation, B.H.; writing—review and editing, B.H. and D.E.; project administration, B.H. and K.L.

Funding: This research received no external funding.

Conflicts of Interest: The authors declare no conflict of interest.

Appendix A. Full Coding Scheme

Table A1. Full Coding Scheme.

\begin{tabular}{llc}
\hline Characteristic & Description & Inter-Coder Reliability \\
\hline Masculine & & 0.87 \\
\hline Curious about princess & $\begin{array}{l}\text { Exhibiting a studious, concerned expression when } \\
\text { looking at the princess. This behavior suggested that the } \\
\text { female had a mystique that was captivating and } \\
\text { romantically compelling. This was only coded for the } \\
\text { prince characters. }\end{array}$ & 1.00 \\
\hline Wants to explore & $\begin{array}{l}\text { To search for, to investigate, to want to find out or } \\
\text { explore the unknown. }\end{array}$ & 0.99 \\
\hline Physically strong & $\begin{array}{l}\text { Hitting or moving something, providing evidence that } \\
\text { the character had a strong physical effect on the person } \\
\text { or object. This was different from a simple athletic } \\
\text { display. There was a separate code for athletic, defined } \\
\text { below, and the codes were mutually exclusive, as it was } \\
\text { understood that displays of physical strength often } \\
\text { incorporated some athleticism. }\end{array}$ & 0.96 \\
\hline Assertive & $\begin{array}{l}\text { Insistence upon a right or claim, the action of declaring } \\
\text { or positively stating. Assertiveness included polite } \\
\text { assertiveness with a hint of aggression. Assertiveness } \\
\text { was a strong, direct assertion of a position or idea. }\end{array}$ & \\
\hline Repression of emotion, indifference to pleasure or pain. \\
A character was unemotional in response to something \\
that might seem to warrant an emotional response, such \\
as a death
\end{tabular}


Table A1. Cont.

\begin{tabular}{|c|c|c|}
\hline Characteristic & Description & Inter-Coder Reliability \\
\hline Independent & $\begin{array}{l}\text { Not depending on the authority of another, autonomous, } \\
\text { self-governing. A character was considered independent } \\
\text { when performing an independent action against many, } \\
\text { being alone when it was not the norm, or not participating } \\
\text { in the expected culture. }\end{array}$ & 1.00 \\
\hline Athletic & $\begin{array}{l}\text { A specific jump or kick that was large enough to require } \\
\text { some athleticism. Running was also coded as athletic. }\end{array}$ & 1.00 \\
\hline $\begin{array}{l}\text { Engaging in } \\
\text { intellectual activity }\end{array}$ & $\begin{array}{l}\text { Engaging the intellect, including reading or showing the } \\
\text { use of thought. }\end{array}$ & 0.97 \\
\hline Inspires fear & $\begin{array}{l}\text { Causing someone to respond with fear, which is defined as } \\
\text { uneasiness caused by the sense of impending danger. This } \\
\text { includes portraying violence and aggression, intimidation, } \\
\text { or unintentionally inspiring fear as well. }\end{array}$ & 0.97 \\
\hline Brave & $\begin{array}{l}\text { Courageous, daring, intrepid. Bravery often involved a } \\
\text { rescue or leadership in the face of danger. }\end{array}$ & 1.00 \\
\hline $\begin{array}{l}\text { Described as physically } \\
\text { attractive (masculine) }\end{array}$ & $\begin{array}{l}\text { A character's expression about the handsomeness of the } \\
\text { prince. }\end{array}$ & 1.00 \\
\hline Gives advice & $\begin{array}{l}\text { Providing suggestions, recommendations or consultation. } \\
\text { This was coded regardless of whether advice was asked } \\
\text { for or whether it was warranted, appreciated, or helpful. }\end{array}$ & 1.00 \\
\hline Leader & $\begin{array}{l}\text { One who leads, a commander. Leader was only coded if } \\
\text { the character was leading a group of people, not animals } \\
\text { and not just him- or herself. It also was only used to } \\
\text { describe physical leadership in which a person is seen in } \\
\text { front of and directing people and involved giving orders. }\end{array}$ & 0.99 \\
\hline \multicolumn{3}{|l|}{ Feminine } \\
\hline $\begin{array}{l}\text { Tends to physical } \\
\text { appearance }\end{array}$ & $\begin{array}{l}\text { Adjusting physical appearance for the purpose of making } \\
\text { it look better or to draw attention to it. }\end{array}$ & 0.78 \\
\hline Physically weak & $\begin{array}{l}\text { Not being able to succeed in something that takes physical } \\
\text { strength. It was often accompanied by needing help or else } \\
\text { failing. }\end{array}$ & 1.00 \\
\hline Submissive & $\begin{array}{l}\text { Yielding to power or authority, humble and ready } \\
\text { obedience. This trait was usually in response to another } \\
\text { character's assertiveness. }\end{array}$ & 0.96 \\
\hline Shows emotion & $\begin{array}{l}\text { The expression of both positive and negative } \\
\text { representation of feeling. This was only coded for princes } \\
\text { because initial piloting of the coding scheme indicated } \\
\text { princesses consistently displayed emotion at each } \\
\text { opportunity throughout and it was unreasonable to code. }\end{array}$ & 1.00 \\
\hline Affectionate & $\begin{array}{l}\text { Having warm regard or love for a person or animal, fond, } \\
\text { loving. This required direct interaction and required a } \\
\text { physical display of love such as a hug, a kiss, or an } \\
\text { individual touch for the point of illustrating affection. }\end{array}$ & 0.93 \\
\hline Nurturing & $\begin{array}{l}\text { To care for and encourage the growth or development of, } \\
\text { to foster. Being nurturing required direct interaction and } \\
\text { was often shown as mothering. It involved prolonged } \\
\text { touching and attention in a soothing manner (different } \\
\text { than a brief instance of affection) or lending care and help } \\
\text { in a loving way to either animals or people. }\end{array}$ & 1.00 \\
\hline
\end{tabular}


Table A1. Cont.

\begin{tabular}{|c|c|c|}
\hline Characteristic & Description & Inter-Coder Reliability \\
\hline Sensitive & $\begin{array}{l}\text { Perception, knowledge, connected with. This code was } \\
\text { distinguished as a form of empathy, as being sensitive } \\
\text { required being aware of another person's or animal's } \\
\text { issues from a distance without interacting directly with } \\
\text { them at that time. }\end{array}$ & 1.00 \\
\hline Tentative & $\begin{array}{l}\text { In an experimental manner, uncertain, cautious, seen in } \\
\text { behavior or speech. }\end{array}$ & 0.99 \\
\hline Helpful & $\begin{array}{l}\text { Rendering or affording help, useful when assistance is } \\
\text { needed. This required a specific action performed that } \\
\text { gave another person or animal direct assistance. It was not } \\
\text { used in a broader way to describe a character's role in a } \\
\text { scene. }\end{array}$ & 0.99 \\
\hline Troublesome & $\begin{array}{l}\text { Causing trouble, turmoil, disturbance. This was recorded } \\
\text { when the character was being discussed by other } \\
\text { characters in a way that made clear that the character had } \\
\text { caused trouble that others were trying to solve. }\end{array}$ & 1.00 \\
\hline Fearful & $\begin{array}{l}\text { An instance of emotion, a particular apprehension of some } \\
\text { future evil, a state of alarm or dread. }\end{array}$ & 1.00 \\
\hline Ashamed & $\begin{array}{l}\text { Affected with shame, the painful emotion arising from the } \\
\text { consciousness of dishonoring and guilt. While both } \\
\text { characters were eligible to be coded for ashamed, it was } \\
\text { only portrayed by the princesses and thus is considered a } \\
\text { female trait. }\end{array}$ & 1.00 \\
\hline Collapses crying & $\begin{array}{l}\text { The character puts his/her face down, such that it was no } \\
\text { longer visible, and cries, usually in rocking shakes and } \\
\text { sobs. Sitting and crying while showing the face did not } \\
\text { count; the character must have thrown him/herself on or } \\
\text { against something (e.g., a bed, the floor) in a statement of } \\
\text { physical and mental helplessness. }\end{array}$ & 1.00 \\
\hline $\begin{array}{l}\text { Described as physically } \\
\text { attractive (feminine) }\end{array}$ & $\begin{array}{l}\text { Another character's expression about the beauty of the } \\
\text { princess. }\end{array}$ & 1.00 \\
\hline $\begin{array}{l}\text { Asks for or accepts } \\
\text { advice or help }\end{array}$ & $\begin{array}{l}\text { The character asks directly for help, or needs assistance } \\
\text { and is open to receiving assistance such that it is clear the } \\
\text { character wants it and accepts it. Assistance could be } \\
\text { physical, mental, or emotional. }\end{array}$ & 1.00 \\
\hline Victim & $\begin{array}{l}\text { Subjected to torture by another, one who suffers severely } \\
\text { in body or property through cruel or oppressive treatment. } \\
\text { Physical harm or abuse was used as a defining factor in } \\
\text { this code. Victimization was coded even if it was } \\
\text { voluntary. }\end{array}$ & 1.00 \\
\hline
\end{tabular}

\section{References}

Abersol, Kaitlin. 2014. How Fourth-Wave Feminism is Changing Disney's Princesses. Available online: http:/ / www.highbrowmagazine.com/4388-how-fourth-wave-feminism-changing-disney-s-princesses (accessed on 1 April 2017).

Aubrey, Jennifer Stevens, and Kristen Harrison. 2004. The gender-role content of children's favorite television programs and its links to their gender-related perceptions. Media Psychology 6: 111-46. [CrossRef]

Baker, Kaysee, and Arthur Raney. 2007. Equally Super? Gender-role stereotyping of superheroes in children's animated programs. Mass Communication and Society 10: 25-41. [CrossRef]

Baker-Sperry, Lori. 2007. The production of meaning through peer interaction: Children and Walt Disney's Cinderella. Sex Roles 56: 717-27. [CrossRef]

Baker-Sperry, Lori, and Liz Grauerholz. 2003. The pervasiveness and persistence of the feminine beauty ideal in children's fairy tales. Gender E Society 17: 711-26. [CrossRef] 
Baumgardner, Jennifer. 2011. F'em! Goo Goo, Gaga, and Some Thoughts on Balls. Berkeley: Seal Press.

Bem, Sandra. 1974. The measurement of psychological androgyny. Journal of Consulting and Clinical Psychology 42: 155-62. [CrossRef] [PubMed]

Bem, Sandra. 1975. Sex role adaptability: One consequence of psychology androgyny. Journal of Personality and Social Psychology 31: 634-43. [CrossRef]

Bem, Sandra. 1981. Gender schema theory: A cognitive account of sex typing. Psychological Review 88: 354-64. [CrossRef]

Béres, Laura. 1999. Beauty and the Beast: The romanticization of abuse in popular culture. European Journal of Cultural Studies 2: 191-207. [CrossRef]

Best, Joel, and Kathleen S. Lowney. 2009. The disadvantage of a good reputation: Disney as a target for social problems claims. The Sociological Quarterly 50: 431-49. [CrossRef]

Blakemore, Judith E. Owen, Sheri A. Berenbaum, and Lynn S. Liben. 2009. Gender Development. New York: Psychology Press.

Box Office Mojo. 2011. Tangled (2010). Available online: http:/ / www.boxofficemojo.com/movies/?id=rapunzel. htm (accessed on 4 May 2017).

Box Office Mojo. 2013. Brave (2012). Available online: http://www.boxofficemojo.com/movies/?id= bearandthebow.htm (accessed on 4 May 2017).

Box Office Mojo. 2014. Frozen (2013) International Box Office Results. Available online: http://www. boxofficemojo.com/movies/?id=frozen2013.htm (accessed on 4 May 2017).

Box Office Mojo. 2017. Moana (2016). Available online: http:/ / www.boxofficemojo.com/movies / ?id=disney1116. htm (accessed on 4 May 2017).

Brave. 2012. Directed by Mark Andrews, and Brenda Chapman. Burbank: Walt Disney Studios Motion Pictures.

Brown, Lyn Mikel, Sharon Lamb, and Mark Tappan. 2009. Packaging Boyhood: Saving Our Sons from Superheroes, Slackers and Other Media Stereotypes. New York: St. Martin's Press.

Browne, Beverly A. 1998. Gender stereotypes in advertising on children's television in the 1990s: A cross-national analysis. Journal of Advertising 27: 83-96. [CrossRef]

Bryman, Alan. 1999. The Disneyization of Society. The Sociological Review 47: 25-47. [CrossRef]

Bussey, Kay, and Albert Bandura. 1999. Social cognitive theory of gender development and differentiation. Psychological Review 106: 676-713. [CrossRef] [PubMed]

Calvert, Sandra L., Jennifer A. Kotler, Sean M. Zehnder, and Erin M. Shockey. 2003. Gender stereotyping in children's reports about educational and informational television programs. Media Psychology 5: 139-62. [CrossRef]

Cheu, Johnson. 2013. Diversity in Disney Films: Critical Essays on Race, Ethnicity, Gender, Sexuality and Disability. London: McFarland.

Cokely, Carrie L. 2005. Someday my prince will come: Disney, the heterosexual Imaginary and animated film. In Thinking Straight: The Power, the Promise, and the Paradox of Heterosexuality. Edited by Chrys Ingraham. London: Routledge, pp. 167-82.

Collins, Rebecca L. 2011. Content analysis of gender roles in media: Where are we now and where should we go? Sex Roles 64: 290-98. [CrossRef]

Connell, Raewyn. 2005. Masculinities. Berkeley: University of California Press.

Coyne, Sarah, Jennifer Ruh Linder, Eric E. Rasmussen, David A. Nelson, and Kevin M. Collier. 2014. It's a bird! It's a plane! It's a gender stereotype!: Longitudinal associations between superhero viewing and gender stereotyped play. Sex Roles 70: 416-30. [CrossRef]

Coyne, Sarah, Jennifer Ruh Linder, Eric E. Rasmussen, David A. Nelson, and Victoria Birkbeck. 2016. Pretty as a princess: Longitudinal effects of engagement with Disney princesses on gender stereotypes, body esteem, and prosocial behavior in children. Child Development 87: 1909-25. [CrossRef] [PubMed]

Davis, Amy M. 2006. Good Girls \& Wicked Witches: Women in Disney's Feature Animation. Hertfordshire: John Libbey Publishing Ltd.

Davis, Amy M. 2013. Handsome Heroes \& Vile Villains: Men in Disney's Feature Animation. Hertfordshire: John Libbey Publishing Ltd.

Dill, Karen E., and Kathryn P. Thill. 2007. Video game characters and the socialisation of gender roles: Young people's perceptions mirror sexist media depictions. Sex Roles 57: 851-64. [CrossRef]

Donaldson, Mike. 1993. What is hegemonic masculinity? Theory and Society 22: 643-57. [CrossRef] 
Do-Rozario, Rebecca-Anne C. 2004. The princess and the magic kingdom: Beyond nostalgia, the function of the Disney princess. Women's Studies in Communication 27: 34-59. [CrossRef]

Dundes, Lauren. 2001. Disney's modern heroine Pocahontas: Revealing age-old gender stereotypes and role discontinuity under a façade of liberation. The Social Science Journal 38: 353-65. [CrossRef]

Dundes, Lauren, Madeline Streiff, and Zachary Streiff. 2018. Storm Power, an Icy Tower and Elsa's Bower: The Winds of Change in Disney's Frozen. Social Sciences 7: 86. [CrossRef]

Dunsmore, Carrie. 2017. Disney's Moana is a Princess Head and Shoulders (and Feet) above the Rest. Available online: https://www.washingtonpost.com/news/parenting/wp/2017/02/09/disneys-moana-is-aprincess-head-and-shoulders-and-feet-above-the-rest/?noredirect=on\&utm_term=.9de019963533 (accessed on 19 April 2018).

Duralde, Alonso. 2016. Dwayne Johnson Invigorates Disney's South Seas Saga. Available online: https:/ www.thewrap. com/moana-review-dwayne-johnson-invigorates-disneys-south-seas-saga/ (accessed on 19 April 2018).

Eagly, Alice H. 2013. Sex Differences in Social Behavior: A Social-Role Interpretation. Hillsdale: Lawrence Erlbaum.

Eagly, Alice H., Wendy Wood, and Amanda B. Diekman. 2000. Social role theory of sex differences and similarities: A current appraisal. In The Developmental Social Psychology of Gender. Edited by Thomas Eckes and Hanns M. Trautner. Mahwah: Lawrence Erlbaum Associates, pp. 123-74.

Eggermont, Steven. 2006. Television viewing and adolescents' judgment of sexual request scripts: A latent growth curve analysis in early and middle adolescence. Sex Roles 55: 457-68. [CrossRef]

England, Dawn E., Lara Descartes, and Melissa A. Collier-Meek. 2011. Gender role portrayal and the Disney princesses. Sex Roles 64: 555-67. [CrossRef]

Foote, Lena. 2010. "I Want to be a Princess Too": Exploring the Blackout of Disney's Princesses and Controversies Surrounding The Princess and the Frog and Its Effects on African American Girls. Film Matters 2: 13-22. [CrossRef]

Frozen. 2013. Directed by Chris Buck and Jennifer Lee. Burbank: Walt Disney Studios Motion Pictures.

Frueh, Terry, and Paul E. McGhee. 1975. Traditional sex role development and the amount of time spent watching television. Developmental Psychology 11: 109. [CrossRef]

Garabedian, Juliana. 2014. Animating gender roles: How Disney is redefining the modern princess. James Madison Undergraduate Research Journal 2: 22-25.

Garlen, Julie C., and Jennifer A. Sandlin. 2017. Happily (n)ever after: The cruel optimism of Disney's romantic ideal. Feminist Media Studies 17: 957-71. [CrossRef]

Gerbner, George, Larry Gross, Michael Morgan, and Nancy Signorielli. 1980. The mainstreaming" of America. Violence Profile No. 11. Journal of Communication 20: 10-27. [CrossRef]

Gerbner, George, Larry Gross, Michael Morgan, and Nancy Signorielli. 1994. Growing up with television: The cultivation perspective. In Media Effects: Advances in Theory and Research. Edited by Jennings Bryant and Doli Zillmann. Hillsdale: Lawrence Erlbaum Associates, Inc., pp. 17-41.

Gill, Rosalind. 2014. Powerful women, vulnerable men and post-feminist masculinity in men's popular fiction. Gender and Language 8: 185-204. [CrossRef]

Gillam, Ken, and Shannon R. Wooden. 2008. Post-princess models of gender: The new man in Disney/Pixar. Journal of Popular Film and Television 36: 2-8. [CrossRef]

Giroux, Henry A., and Grace Pollock. 2010. The Mouse That Roared: Disney and the End of Innocence. Lanham: Rowman \& Littlefield.

Golden, Julia C., and Jennifer Wallace Jacoby. 2017. Playing Princess: Preschool Girls' Interpretations of Gender Stereotypes in Disney Princess Media. Sex Roles, 1-15. [CrossRef]

Gomez, Jeff. 2014. Why 'Frozen' Became the Biggest Animated Movie of All Time. Available online: http:/ / www.businessinsider.com/why-frozen-is-a-huge-success-2014--4?IR=T (accessed on 5 May 2017).

Graves, Sherryl Browne. 1999. Television and prejudice reduction: When does television as a vicarious experience make a difference? Journal of Social Issues 55: 707-25. [CrossRef]

Gregory, Sarita. 2010. Disney's Second Line: New Orleans, Racial Masquerade, and the Reproduction of Whiteness in The Princess and the Frog. Journal of African American Studies 14: 432-49. [CrossRef]

Griffin, Sean. 2000. Tinker Belles and Evil Queens: The Walt Disney Company from the Inside Out. New York: NYU Press.

Hartwell, Lisa M. 2015. A Content Analysis of Gender Portrayals in Disney Films in Comparison to Miyazaki Films. Unpublished Bachelor's thesis, University of Pittsburgh, Pittsburgh, PA, USA. 
Hefner, Veronica, Rachel-Jean Firchau, Katie Norton, and Gabriella Shevel. 2017. Happily Ever After? A Content Analysis of Romantic Ideals in Disney Princess Films. Communication Studies 68: 511-32. [CrossRef]

Hentges, Beth, and Kim Case. 2013. Gender representations on Disney Channel, Cartoon Network, and Nickelodeon broadcasts in the United States. Journal of Children \& Media 7: 319-33. [CrossRef]

Herrett-Skjellum, Jannifer, and Mike Allen. 1996. Television programming and sex stereotyping: A meta-analysis. In Communication Yearbook 19. Edited by Brant R. Burleson. Thousand Oaks: SAGE, pp. 663-80.

Hine, Benjamin, Katarina Ivanovic, and Dawn England. 2018. From the sleeping princess to the world-saving daughter of the chief: Examining young children's perceptions of 'old' versus 'new' Disney princess characters. Social Sciences 7: 161. [CrossRef]

Hogg, Michael A., Deborah J. Terry, and Katherine M. White. 1995. A tale of two theories: A critical comparison of identity theory with social identity theory. Social Psychology Quarterly 58: 355-69. [CrossRef]

Holmes, Bjarne M. 2007. In search of my one-and-only": Romance-related media and beliefs in romantic relationship destiny. The Electronic Journal of Communication 17: 1-29.

Hugel, Melissa. 2013. How Disney Princesses Went from Passive Damsels to Active Heroes. Available online: https:/ / mic.com/articles/73093/how-disney-princesses-went-from-passive-damsels-to-activeheroes\#.1To66Am78 (accessed on 25 March 2017).

Hust, Stacey J. T., and Jane D. Brown. 2008. Gender, media use, and effects. In The Handbook of Children, Media, and Development. Edited by Sandra L. Calvert and Barbara J. Wilson. Oxford and Malden: Blackwell, pp. 98-120.

John, Beynon. 2002. Masculinities and the notion of 'crisis'. In Masculinities and Culture. Edited by Beynon John. Philadelphia: Open University Press.

Kollmayer, Marlene, Marie-Therese Schultes, Barbara Schober, Tanja Hodosi, and Christiane Spiel. 2018. Parents' judgments about the desirability of toys for their children: Associations with gender role attitudes, gender-typing of toys, and demographics. Sex Roles, 1-13. [CrossRef] [PubMed]

Koonikova, Maria. 2014. “How Frozen” Took over the World. Available online: http:/ /www.newyorker.com/ science/maria-konnikova/how-frozen-took-over-the-world (accessed on 25 February 2017).

Krippendorf, Klaus. 2004. Content Analysis: An Introduction to Its Methodology. Thousand Oaks: SAGE.

Lacroix, Celeste. 2004. Images of animated others: The orientalization of Disney's cartoon heroines from the Little Mermaid to the Hunchback of Notre Dame. Popular Communication 2: 213-29. [CrossRef]

Leaper, Campbell, Lisa Breed, Laurie Hoffman, and Carly Ann Perlman. 2002. Variations in the gender-stereotyped content of children's television cartoons across genres. Journal of Applied Social Psychology 32: 1653-62. [CrossRef]

Lemish, Dafna. 2010. Screening Gender on Children's Television: The Views of Producers around the World. New York: Routledge.

Li-Vollmer, Meredith, and Mark LaPointe. 2003. Gender transgression and villainy in animated film. Popular Communication 1: 89-109. [CrossRef]

Lopreore, Katie M. 2016. Gender Role Portrayals of Modern Disney Royalty: Stereotypical or Androgynous? Unpublished Master's thesis, Middle Tennessee State University, Murfreesboro, TN, USA.

Luther, Catherine A., and Robert Legg, Jr. 2010. Gender differences in depictions of social and physical aggression in children's television cartoons in the US. Journal of Children $\mathcal{E}$ Media 4: 191-205. [CrossRef]

Macaluso, Michael. 2018. Postfeminist Masculinity: The New Disney Norm? Social Sciences 7: 221. [CrossRef]

Machado, Yolanda. 2016. Directors Reveal How They Made Disney's Next Hit. Available online: https://www. moviefone.com/2016/11/23/moana-directors-reveal-how-they-made-disneys-next-hit/ (accessed on 19 April 2018).

Macnamara, Jim R. 2005. Media content analysis: Its uses, benefits and best practice methdology. Asia-Pacific Public Relations Journal 6: 1-34.

Marsh, Sarah. 2016. The Gender-Fluid Generation: Young People on Being Male, Female or Non-Binary. Available online: https://www.theguardian.com/commentisfree/2016/mar/23/gender-fluid-generation-youngpeople-male-female-trans (accessed on 19 April 2018).

Martin, Carol L., and Charles F. Halverson. 1981. A Schematic Processing Model of Sex Typing and Stereotyping in Children. Child Development 52: 1119-34. [CrossRef]

Martin, Carol L., Diane N. Ruble, and Joel Szkrybalo. 2002. Cognitive Theories of Early Gender Development. Psychological Bulletin 128: 903-33. [CrossRef] [PubMed] 
Martin, Carol L., Naomi C. Z. Andrews, Dawn E. England, Kristina Zosuls, and Diane N. Ruble. 2016. A dual identity approach for conceptualizing and measuring children's gender identity. Child Development. [CrossRef] [PubMed]

Matyas, Vanessa. 2010. A Textual Analysis of Race and Gender in Disney Princess Films. Unpublished Master's thesis, McMaster University, Hamilton, ON, Canada.

Mead, George H. 1934. Mind, Self E Society. Edited by Charles W. Morris. Chicago: University of Chicago Press, pp. 227-34.

Moana. 2016. Directed by Ron Clements and John Musker. Burbank: Walt Disney Studios Motion Pictures.

Morr-Serewicz, Mary C., and Elaine Gale. 2008. First-date scripts: Gender role, context, and relationship. Sex Roles 58: 149-64. [CrossRef]

Neuendorf, Kimberly A. 2002. The Content Analysis Guidebook. Thousand Oaks: SAGE.

Ngata, Tina. 2016. Despite Claims of Authenticity, Disney's Moana Still Offensive. Available online: http:/ / www.risingupwithsonali.com/despite-claims-of-authenticity-disneys-moana-still-offensive (accessed on 19 April 2018).

Northup, Temple, and Carol M. Liebler. 2010. The good, the bad, and the beautiful: Beauty ideals on the Disney and Nickelodeon channels. Journal of Children \& Media 4: 265-82. [CrossRef]

Oliver, Mary B., and Stephen Green. 2001. Development of gender differences in children's response to animated entertainment. Sex Roles 45: 67-88. [CrossRef]

Orenstein, Peggy. 2006. What's Wrong with Cinderella? Available online: http:/ /www.nytimes.com/2006/12/ 24/magazine/24princess.t.html?_r=0 (accessed on 10 December 2018).

Orenstein, Peggy. 2011. Cinderella Ate My Daughter. New York: HarperCollins.

Primo, Cassandra. 2018. Balancing Gender and Power: How Disney's Hercules Fails to Go the Distance. Social Sciences 7: 240. [CrossRef]

Pulver, Andrew. 2016. How Disney's Princesses Got Tough. Available online: https:/ /www.theguardian.com/ film/2016/may/26/has-disney-finally-given-up-on-princesses (accessed on 10 April 2017).

Ramadan, Nada. 2015. Aging With Disney and the Gendering of Evil. Journal of Literature and Art Studies 5: 114-27. [CrossRef]

Riff, Daniel, Stephen Lacy, and Frederick Fico. 2014. Analyzing Media Messages: Using Quantitative Content Analysis in Research. New York: Routledge.

Rudy, Rena M., Lucy Popova, and Daniel G. Linz. 2010a. Content Analysis [Special Issue]. Sex Roles 62: $705-847$. [CrossRef] [PubMed]

Rudy, Rena M., Lucy Popova, and Daniel G. Linz. 2010b. The context of current content analysis of gender roles: An introduction to a special issue. Sex Roles 62: 705-20. [CrossRef] [PubMed]

Saladino, Caitlin J. 2014. Long May She Reign: A Rhetorical Analysis of Gender Expectations in Disney's Tangled and Disney/Pixar's Brave. Unpublished Bachelor's thesis, University of Nevada, Reno, NV, USA.

Signorielli, Nancy. 1990. Children, television, and gender roles: Messages and impact. Journal of Adolescent Health Care 11: 50-58. [CrossRef]

Signorielli, Nancy. 2001. Television's gender-role images and contribution to stereotyping: Past, present, and future. In Handbook of Children and the Media. Edited by Dorothy G. Singer and Jerome L. Singer. Thousand Oaks: Sage, pp. 341-58.

Signorielli, Nancy, George Gerbner, and Michael Morgan. 1995. Violence on television: The cultural indicators project. Journal of Broadcasting \& Electronic Media 39: 278-83. [CrossRef]

Steyer, Isabella. 2014. Gender representations in children's media and their infleunce. Campus-Wide Information Systems 31: 171-80. [CrossRef]

Stover, Cassandra. 2013. Damsels and heroines: The conundrum of the post-feminist Disney princess. LUX: A Journal of Trandisciplinary Writing and Research from Claremont Graduate University 2: 29. [CrossRef]

Streiff, Madeline, and Lauren Dundes. 2017a. From shapeshifter to lava monster: Gender stereotypes in Disney's Moana. Social Sciences 6: 91. [CrossRef]

Streiff, Madeline, and Lauren Dundes. 2017b. Frozen in Time: How Disney Gender-Stereotypes Its Most Powerful Princess. Social Sciences 6: 38. [CrossRef]

Tangled. 2010. Directed by Nathan Greno and Byron Howard. Burbank: Walt Disney Studios Motion Pictures.

The Princess and the Frog. 2009. Directed by Ron Clements and John Musker. Burbank: Walt Disney Studios Motion Pictures. 
The Walt Disney Company. 2016. Dream Big Princess. Available online: https://partners.disney.com/dream-bigprincess-photo-campaign (accessed on 29 October 2018).

The Walt Disney Company. 2017. The Walt Disney Company Reports Fourth Quarter and Full Year Earnings for Fiscal 2017. Available online: https:/ / www.thewaltdisneycompany.com/walt-disney-company-reportsfourth-quarter-full-year-earnings-fiscal-2017/ (accessed on 15 February 2018).

Thompson, Teresa, and Eugenia Zerbinos. 1995. Gender roles in animated cartoons: Has the picture changed in 20 years? Sex Roles 32: 651-73. [CrossRef]

To, Benjamin. 2016. Dance, Storytelling and the Art of Wayfinding: Behind the Scenes of Disney's Moana. Available online: http:/ / www.nbcnews.com/news/asian-america/dance-storytelling-art-wayfinding-behind-scenesdisney-s-moana-n672141 (accessed on 19 April 2018).

Towbin, Mia A., Shelley A. Haddock, Toni S. Zimmerman, Lori K. Lund, and Litsa R. Tanner. 2004. Images of gender, race, age, and sexual orientation in Disney feature-length animated films. Journal of Feminist Family Therapy 15: 19-44. [CrossRef]

Wiersma, Beth A. 2001. The gendered world of Disney: A content analysis of gender themes in full-length animated Disney feature films [Abstract]. Dissertation Abstracts International 61: 4973.

Williams, Tannis M. 1981. How and what do children learn from television? Human Communication Research 7: 180-92. [CrossRef]

Wohlwend, Karen E. 2009. Damsels in discourse: Girls consuming and producing identity texts through Disney princess play. Reading Research Quarterly 44: 57-83. [CrossRef]

(C) 2018 by the authors. Licensee MDPI, Basel, Switzerland. This article is an open access article distributed under the terms and conditions of the Creative Commons Attribution (CC BY) license (http://creativecommons.org/licenses/by/4.0/). 